\title{
Modus Pelayanan Bimbingan dan Konseling Islam Sebagai Upaya Pencegahan Bahaya Narkoba
}

\author{
Yakub $^{1}$, Abdurrahman ${ }^{2}$ \\ ${ }^{1}$ Universitas Islam Negeri Syarif Hidayatullah, ${ }^{2}$ Universitas Islam Negeri Sumatera Utara \\ 2abdurrahman@uinsu.ac.id

$\begin{array}{ccc}\text { First received: } & \text { Revised: } & \text { Final Accepted: } \\ \text { 21 January } 2019 & \text { 23 February 2019 } & \text { 04 May } 2019\end{array}$

\begin{abstract}
The purpose of this study was to find information about the implementation of Islamic guidance and counseling services in State Islamic Senior High Schools in the City of Medan. This type of research is qualitative with descriptive type. The object of the research is the State Aliyah Madrasah in Medan City, the subjects are the Guidance and Counseling coordinator and Guidance and Counseling Teachers. The technique to data collection uses interview, observation, and documentation study methods. Data were analyzed using data triangulation approach. Based on the findings, the implementation of counseling services in Medan City Aliyah Madrasas in the category of very good and good. The effectiveness of the service is in a very good.
\end{abstract}

Keywords: Prevention, Drugs, Islamic Guidance and Counselling

\begin{abstract}
Abstrak
Tujuan penelitian ini adalah untuk mencari informasi tentang pelaksanaan layanan bimbingan dan konseling Islam di Madrasah Aliyah Negeri di Kota Medan. Jenis penelitian ini adalah kualitatif dengan jenis deskriptif. Objek penelitian adalah Madrasah Aliyah Negeri di Kota Medan, subjek adalah koordinator Bimbingan dan Konseling serta Guru Bimbingan dan Konseling. Teknik Pengumpulan data menggunakan metode wawancara, observasi, dan studi dokumentasi. Data dianalisis dengan pendekatan triangulasi data. Berdasarkan temuan, pelaksanaan layanan konseling di Madrasah Aliyah Negeri Se-Kota Medan pada kategori sangat baik dan Baik. Efektivitas pelayanan berada pada kategori sangat baik.

Kata Kunci: Pencegahan, Narkoba, Bimbingan dan Konseling Islami
\end{abstract}

\section{PENDAHULUAN}

Bahaya narkoba dewasa ini semakin mengancam kehidupan remaja. Namun data yang terhimpun akhir-akhir ini menunjukkan bahwa penggunaan narkoba tidak hanya pada kalangan orang dewasa saja. Bahkan, narkoba sudah dikonsumsi oleh anak-anak dan remaja. Menurut Badan Narkotika Nasional (Selanjutnya disebut BNN) pada tahun 2007 terdapat 18.702 pengguna pada tingkatan Sekolah Dasar (SD), Sekolah Menengah Pertama (SMP), dan Sekolah Menengah Atas (SMA). Data tersebut terus meningkat.
Remaja harus waspada terhadap bahaya narkoba. Tidak hanya dapat merusak fisik dan kejiwaan, bahkan dapat menyebabkan kematian bagi para penggunanya. Sifat adiksi dalam narkoba dapat mempengaruhi fisik maupun psikologis bagi remaja sebagai pengguna. Pada dasarnya narkoba merupakan zat yang digunakan untuk pengobatan dan penelitian. Tetapi penyalahgunaan menjadikan zat narkoba menjadi zat yang terlarang dan tidak boleh dikonsumsi tanpa indikasi yang jelas.

Sumatera utara adalah salahsatu daerah dengan pengguna narkoba pada 
kategori tinggi. Hal ini sesuai dengan berita yang dirilis oleh Republika pada tanggal 27 Agustus 2017, yang menyatakan bahwa Badan Narkotika Nasional (Selanjutnya disebut BNN) merilis ada 350 ribu pengguna narkoba di Sumatera Utara (Aminah, 2017). Lebih lanjut Kepala BBNProvinsi Sumatera Utara, Andi Leodianto mengungkapkan bahwa 350 ribu pengguna narkoba tersebut berada pada rentang usia 10-59 tahun. Serta angka prevalensi masyarakat yang berisiko terpapar narkoba di Sumatera Utara masih sangat tinggi sehingga harus ada upaya pencegahan dan pemberantasan yang lebih gencar (Sumut, 2017).

Maka dari itu perlunya gerakan yang sistematis untuk pencegahan penyalahgunaan narkoba guna menekan angka prevelansi yang sangat tinggi. Banyak hal yang bisa dilakukan untuk mencegah penyalahgunaan narkoba. Diantaranya dapat menggunakan pelayanan bimbingan konseling islam dengan pendekatan kearifan lokal yang ada di sumatera utara. Menurut Natawidjaja yang mengartikan bahwa bimbingan sebagai proses pemberian bantuan kepada individu yang dilakukan secara berkesinambungan, supaya individu tersebut dapat memahami dirinya, sehingga dia sanggup mengarahkan dirinya dan dapat bertindak secara wajar, sesuai dengan tuntutan dan keadaan lingkungan sekolah, keluarga, masyarakat, dan kehidupan pada umumnya (Natawidjaja, 1987).

Pelayanan bimbingan konseling islam pada dasarnya identik dengan pengentasan permasalahan yang ada di lingkungan sekolah. Tetapi, prinsip bimbingan konseling islam itu sendiri yaitu pelayanan di sekolah mantap, di luar sekolah sigap, dan dimana-mana siap. Dan salah satu fungsi yang ada dalam bimbingan konseling islam adalah fungsi pencegahan atau preventif. Sehingga pelayanan bimbingan konseling islam diharapkan mampu memberikan kontribusi dalam gerakan pencegahan bahaya penyalahgunaan narkoba.

\section{METODE}

Penelitian ini menggunakan pendekatan kualitatif jenis deskriptif. Pemilihan pendekatan ini didasarkan bahwa data yang hendak dicari adalah data yang menggambarkan pola pencegahan narkoba berbasis pelayanan konseling islam. Penelitian dilaksanakan di Sekolah Madrasah Aliyah Negeri Se-Kota Medan. Alasan pengambilan lokasi penelitian tersebut yaitu melihat aspek pelaksanaan layanan konseling yang berorientasikan islam. Adapun yang menjadi responden/informan dalam penelitian ini adalah pihak yang aktif dan terkait langsung dalam proses pelayanan bimbingan dan konseling di sekolah. Hal ini dilakukan dengan mengambil beberapa orang sebagai key informan dengan system Purposive Sampling. Teknik ini dipakai karena adanya pertimbangan tertentu seperti informan adalah orang yang paling mengetahui pelaksanaan layanan bimbingan dan konseling di sekolah. Dalam penelitian ini yang menjadi informan penelitian adalah koordinator Guru BK dan Guru BK yang melakukan pelayanan konseling. Penelitian ini menggunakan tiga teknik pengumpulan data. Pada pendekatan Kualitatif, teknik yang digunakan adalah Wawancara, Observasi, dan Studi Dokumentasi. Teknik analisis data dalam penelitian ini menggunakan tiga tahap atau proses yakni reduksi data (data reduction), pengorganisasian (organisation), dan interpretasi data (interpretation). 


\section{HASIL TEMUAN}

\section{Temuan Umum}

MAN 1 Medan (dahulunya MAN Medan) adalah cikal bakal berdirinya seluruh MAN yang ada di Kota Medan. Dikarenakan terjadi perubahan tuntutan kebutuhan terhadap kualitas guru mata pelajaran Pendidikan Agama Islam dengan mensyaratkan lulusan Diploma II, maka PGAN 6 tahun dilikuidasi oleh pemerintah menjadi MAN pada tahun 1992. Maka sejak itulah MAN Medan berubah menjadi MAN-1 Medan (Tarmizi, 2018). MAN 1 Medan memiliki 6 Guru BK yang mana sebagai koordinator adalah Amir Husin Pangaribuan, M.Pd., Kons. Selain itu Guru BK di MAN 1 Medan ada yang berlatar belakang Psikologi.

MAN 2 Medan adalah sekolah rintisan yang merupakan kelanjutan dari Pendidikan Guru Agama Negeri (PGAN) yang kemudian berubah menjadi MAN 2 Model Medan pada tahun 1988. Sampai saat ini MAN 2 Model Medan masih tetap eksis berada di jalan Willem Iskandar No. 7A Kelurahan Sidorejo, Kecamatan Medan Tembung, Kota Medan. Perjalanan panjang yang telah dilalui MAN 2 Model Medan dari awal berdirinya hingga sekarang membuat MAN 2 Model Medan benarbenar mampu menjadi sekolah yang matang, sesuai dengan usia dan pengalaman yang telah dilaluinya sehingga mampu melahirkan siswa-siswa yang kelak dikemudian hari menjadi orang-orang penting, sukses dan berguna di tengahtengah masyarakat, negara, bangsa dan agama. Semua kesuksesan tersebut tidak lepas dari hasil jerih payah segenap guru-guru dan staf MAN 2 Model Medan yang ikhlas memberikan ilmunya dan mendidik siswa/siswi sampai sekarang. Sementara itu, saat ini MAN 2
Medan memiliki 6 Guru BK yang terdiri dari 2 Koordinator dan 4 Guru BK. Dikarenakan MAN 2 Medan memiliki 2 lokasi kampus, maka 1 Koordinator bertugas di Kampus Pancing, dan 1 koordinator lagi bertugas di Kampus Helvetia. Dan Guru BK MAN 2 Medan tidak dari lulusan BK/BKI saja, melaikan ada Guru BK yang dari lulusan Psikologi dan Guru Mata pelajaran diperbantukan sebagai Guru BK.

MAN 3 Medan lahir dilatarbelakangi oleh banyaknya peminat MAN 1 Medan, sehingga MAN 1 Medan membuka program kelas jauh yang berada di Patumbak. Seiring perkembangan waktu, semakin meningkatnya jumlah siswa di kelas jauh, maka pemerintah pusat menetapkan dan mendirikan MAN 3 Medan pada tahun 1996. MAN 3 Medan sangat berkembang pesat hingga sekarang. MAN 3 Medan secara terus-menerus telah menunjukan hasil yang sangat baik sebagai pendidikan SMA berciri khas Islam. Berbagai prestasi banyak diraih baik prestasi di bidang akademik maupun non akademik, baik dari tingkat SLTA/MA dan PT, Daerah, Kabupaten/kota, Regional, Provinsi, dan Nasional. MAN 3 Medan sebagai salah satu lembaga pendidikan Islam tingkat Menengah Atas, berusaha keras untuk membentuk insan yang beriman Membentuk insan yang beriman, berakhlaqulkarimah, berilmu, kreatif, serta peduli dengan lingkungan dan masyarakat". Juga mewujudkan Madrasah yang menjadi lembaga Pendidikan Islam yang modren, profesional dan populer yang mampu menjawab tantangan dan tuntutan di massa datang. Saat ini MAN 3 Medan memiliki 6 Guru BK. 4 Guru BK berlatar belakang bimbingan dan Konseling, 1 Guru BK berlatar belakang 
Pendidikan fisika, dan 1 Guru BK berlatar belakang Pendidikan Bahasa Indonesia. Berikut nama-nama Guru BK di MAN 3 Medan.

MAPN 4 Medan adalah sekolah persiapan yang dibangun oleh Kemenag pada tahun 2010. MAP 4 Medan memiliki visi yaitu Unggul, Islami, Berkualitas dan Berwawasan Lingkungan. Berdasarkan visi tersebut MAP 4 Medan melaksanakan sistem pembelajaran yang mengacu pada Struktur program yang menitikberatkan pada penguasaan IPTEK, IMTAQ serta penguasaan Bahasa Inggeris dan Bahasa Arab, Kurikulum diperkaya dengan pendidikan yang mengarah pada keterampilan hidup (life skill), menggunakan pendekatan intelektual, kegiatan, keteladanan dan laboratorium, dan melaksanakan pembelajaran full day school. Saat ini MAPN 4 Medan hanya memiliki 2 Guru BK. 1 Orang berlatar belakang BK dan 1 Guru BK berlatar belakang Kimia Non Kependidikan.

\section{Modus Layanan Bimbingan Konseling Islam Sebagai Upaya Pencegahan Bahaya Narkoba di MAN 1 Medan}

Secara umum program bimbingan dan konseling merupakan suatu rancangan atau rencana kegiatan yang akan dilaksanakan dalam jangka waktu tertentu. Sedangkan, program bimbingan dan konseling ialah suatu rangkaian kegiatan bimbingan dan konseling yang tersusun secara sistematis, terencana, terorganisasi, dan terkoordinasi selama periode waktu tertentu. Oleh karena itu berdasarkan wawancara yang peneliti lakukan oleh guru BK di MAN 1 Medan, dalam membuat program, maka pihak guru BK melakukan perencanaan terlebih dahulu. Perlu diperhatikan, dalam merencanakan program-program layanan bimbingan konseling, perlu melibatkan pihakpihak yang dapat menunjang keberhasilan layanan bimbingan dan konseling. Koordinasi dan kerja sama dengan berbagai pihak yang terkait sangat diperlukan untuk menyusun rencana program BK. Dengan demikian, diharapkan hasil dari program yang telah disusun dapat memenuhi kebutuhan berbagai pihak di sekolah dan madrasah yang bersangkutan.

Koordinator Guru BK di MAN 1 Medan adalah orang yang professional dibidang bimbingan dan konseling. Hal ini dapat dilihat dari Pendidikan formal yang ditempuh yaitu Strata 1 dan Strata 2 Bimbingan dan Konseling, serta Pendidikan Profesi Konselor. Guru BK yang lain juga merupakan guru yang liner pada bidangnya. Istimewanya terdapat Guru BK alumni dari Strata 1 Bimbingan dan Konseling Islam UIN Sumatera Utara. Sehingga peneliti menyimpulkan pelayanan bimbingan dan konseling di MAN 1 Medan sudah berjalan tepat pada jalurnya. Terlebih adanya alumni dari Bimbingan dan Konseling Islam, yang notabenenya akan mempengaruhi pelayanan bimbingan dan konseling serta penyusunan program bimbingan dan konseling yang memuat nilai-nilai islami dalam setiap pelayanannya.

Selanjutnya, Koordinator BK dan Guru BK di MAN 1 Medan tidak lupa pula memberikan layanan-layanan yang memuat materi tentang bahaya narkoba. Hal ini dikarenakan kekhawatiran guru dan orangtua akan bahaya narkoba yang bisa saja menyerang peserta didik. Contoh penyampaian tentang bahaya narkoba melalui layanan informasi yang diselenggarakan secara klasikal maupun menggunakan pendekatan media.

Contoh kasus lain jika ada siswa yang ketahuan merokok di luar sekolah, maka 
guru BK tidak segan untuk memberikan teguran dan nasehat kepada peserta didik. Hal ini dilakukan karena awal mula mencoba narkoba dapat diawali dengan mencoba merokok. Dalam konteks konseling Islami, nasihat menjadi salah satu bagian yang tidak terpisahkan dan dianggap menjadi sebuah teknik dasar untuk menyadarkan konseli, sesuai hadits. Dalam hal ini guru BK, terus mengingatkan konseli untuk belajar dengan giat agar kelak, konseli menjadi orang yang sukses, dan menjadi insan yang bermanfaat bagi masyarakat dan ummat serta berguna bagi nusa dan bangsa. Sedangkan, keinginan konseli untuk menghisap rokok lagi akan perlahan hilang, dikarenakan nasehat yang diberikan diresapi oleh siswa. Sejauh pengalaman menjadi guru di MAN 1 Medan belum ada ditemukan siswa yang ketahuan memakai narkoba atau ditangkap sebagai pemakai narkoba.

Memahami dengan seksama cara yang dilakukan oleh Guru BK tersebut di atas dalam menangani masalah siswa, dapat dikatakan sudah cukup baik. Artinya, mula-mula guru BK membangun hubungan yang baik dengan konseli, agar konseli merasa tenang, disayangi, dan diperhatikan oleh gurunya. Kemudian, sambutan yang hangat dan penuh perhatian dalam proses konseling memang menjadi alasan utama, timbulnya sikap terbuka bagi konseli untuk menyampaikan masalahnya. Emosi yang stabil yang ditunjukkan oleh guru BK menunjukkan kompetensi kepribadian yang matang, dapat membangun sebuah stigma positif di benak konseli, sehingga dapat memudahkan konselor untuk membangun komunikasi yang efektif. Seakan-akan, tanpa diminta sekalipun citra yang ditampilkan menjadi salah satu alasan bagi konseli untuk meneladaninya. Tidak hanya itu, bimbingan yang disampaikan oleh guru BK secara santun seperti air sejuk yang mendinginkan hati konseli untuk menerima masukannya.

\section{Modus Layanan Bimbingan Konseling Islam Sebagai Upaya Pencegahan Bahaya Narkoba di MAN 2 Medan}

Selanjutnya dalam menjalankan kegiatan bimbingan dan konseling, MAN 2 Model Medan memiliki beberapa tenaga ahli yang aktif memberikan layanan dan memantau seluruh aktivitas kegiatan siswa berkaitan dengan program bimbingan dan konseling. Hal unik terjadi di MAN 2 Medan dimana Koordinator Guru BK yang beralamat kampus pancing merupakan bukan alumni dari jurusan bimbingan dan konseling maupun bimbingan dan konseling islam. Melaikan alumni dari Psikologi Universitas Sumatera Utara. Jika ditinjau dari segi Pendidikan, akan terlihat jelas bahwa terdapat perbedaan antara psikologi dan bimbingan dan konseling seperti program-program serta layanan yang diberikan kepada konselinya.

Akan tetapi, dalam pelaksanaan pelayanan bimbingan dan konseling, koordinator BK di MAN 2 Medan dibantu oleh beberapa guru BK yang berlatar belakang jurusan bimbingan dan konseling islam. Sehingga peneliti menarik kesimpulan bahwa pelayanan bimbingan dan konseling islam yang dilaksanakan di MAN 2 Medan dapat berjalan dengan baik sesuai dengan kaidah pelayanan bimbingan dan konseling. Hal ini terlihat pada saat observasi, peneliti menyaksikan Koordinator Guru BK memberikan layanan informasi di kelas.

Menurut penyampaian Bapak Khairun Naim, S.Pd.I selaku guru BK di MAN 2 Model Medan, bahwa dalam 
merencanakan program BK ada hal-hal yang menjadi acuan, yakni:

Program yang baik adalah program yang sesuai (match) kebutuhan konseli seperti: Kebutuhan aktualisasi diri dan pemenuhan diri (self-actualization needs) seperti pengembangan potensi diri. Kebutuhan harga diri (esteem needs) seperti status atau kedudukan, kepercayaan diri, pengakuan, reputasi, kehormatan diri dan penghargaan. Kebutuhan sosial (social needs) seperti cinta, persahabatan, perasaan memiliki, kekeluargaan dan asosiasi. Kebutuhan keamanan dan rasa aman (safety and security needs) seperti perlindungan dan stabilitas. Kebutuhan fisiolgis (physiological needs) seperti makan, minum, perumahan, seks dan istirahat. Semua kebutuhan di atas perlu di analisis untuk ditetapkan kebutuhan mana yang akan diprioritaskan untuk diberikan pelayanan bimbingan konseling.

pengumpulan data non tes merupakan prosedur pengumpulan data yang dirancang untuk memahami pribadi peserta didik, yang pada umumya bersifat kualitatif. Teknik ini tidak memakai alatalat yang bersifat mengukur, namun hanya memakai alat yang bersifat menghimpun atau mendeskripsikan saja. Teknik nontes menghasilkan jawaban yang tidak dapat dikategorikan salah atau benar, tetapi semuanya sesuai dianggap benar bila jawaban yang dimaksud sesuai dengan kondisi atau karakteristik responden. Adapun yang termasuk teknik non-tes adalah: observasi, wawancara, angket, catatan anekdot, autobiografi, sosiometri, studi kasus, studi dokumentasi, konferensi kasus dan alat inventori lainnya (AUM, ITP, DCM, IKMS).

Menurut penuturan Ibu Zuaraidah, S.Psi, bahwa Dalam merencanakan kegiatan bimbingan konseling Islami di
Identifikasi kebutuhan siswa dilakukan dengan cara melakukan asesmen, baik yang bersifat tes maupun yang non tes.43 Teknik tes merupakan upaya untuk memahami konseli dengan menggunakan alat-alat atau instrumen yang bersifat mengukur atau tes. Rintisan awal terhadap tes dalam dunia psikologi dan juga bimbingan dan konseling sebenarnya dipacu oleh kebutuhan untuk mengembangkan sistem dan mengklasifikasikan tingkat dan jenis keterbelakangan yang berbeda-beda yang dialami oleh penderita keterbelakangan mental hingga sampai sekarang ini tes mampu mengukur aspek intelektual individu namun untuk mengukur aspek nonintelektual (kepribadian) sampai saat terus dikembangkan. Adapaun ragam bentuk pengukuran melalui tes adalah tes hasil belajar, tes kecerdasan (IQ), tes bakat, tes minat, dan tes kepribadian. Sedangkan teknik

MAN 2 Model Medan guru BK selalu bekerja sama. Jika dilihat latar belakang pendidikan masing-masing guru BK tampanya merupakan unsur gabungan yang ideal ada yang berlatar belakang pendidikan BK Islam, ada yang berlatar belakang BK konvensional, dan ada yang berlatar belakang psikologi. Sehingga, masing-masing guru BK bersama-sama dalam mengembangkan program Bimbingan Konseling Islami di Madrasah ini. Adapun hal yang berkaitan dengan perencanaan ini, guru BK menyepakati tentang bidang bimbingan yang menjadi dasar pelaksanaan layanan, selanjutnya setelah menentukan bidang layanan, maka selanjutnya menentukan instrumen yang digunakan untuk melihat kebutuhan siswa akan bidang-bidang tersebut tadi, sehingga pelaksanaan layanan bimbingan konseling Islami dapat benar-benar program yang dibutuhkan oleh siswa. 
Selain itu, MAN 2 Medan dalam melakukan pelayanan bimbingan dan konseling islam didukung oleh sarana dan prasarana yang memadai. Hal ini disampaikan oleh Koordinator Guru BK kepada peneliti bahwasannya Sarana dan fasilitas yang dipenuhi adalah sarana dan fasilitas yang berkaitan langsung dengan proses pemberian Bimbingan Konseling di MAN 2 Model Medan. Sarana dan fasilitas ini sifatnya adalah membantu Konselor sekolah untuk memudahkan kerja-kerja bimbingan dan konseling. Adapun sarana dan fasilitas yang sudah dipenuhi yaitu ruangan khusus bimbingan dan konseling, Meja piket, Lemari, buku proses masalah, buku hasil proses masalah, dan juga laptop yang dibutuhkan dalam pelaksanaan bimbingan dan konseling.

Selanjutnya, sesuai dengan keterangan yang diberikan oleh Koordinator Guru BK, maka peneliti melakukan penelitian langsung berkaitan dengan sarana dan prasarana pelaksanaan kegiatan bimbingan dan konseling islam di MAN 2 Medan termasuk lengkap, Ruang pelayanan BK yang representatif, terdapat meja dan kursi, ada lemari instrument dan lemari data, serta beberapa poster media layanan yang tertempel di ruangan maupun di beberapa dinding sekolah.

Dalam pelaksanaan kegiatan bimbingan dan konseling islam di MAN 2 Medan sejauh ini tidak mengalami hambatan yang cukup berarti. Karena dala setiap proses konseling siswa mampu memahami hingga dapat mengambil keputusan yang akan dilakukannya kelak. Terlebih jika berkaitan dengan narkoba. Guru BK MAN 2 Medan tidak luput menyertakan materi tentang bahaya narkoba dikalangan remaja. Materai tentang narkoba tersebut disisipkan nilainilai islami yang diberikan kepada siswa sehingga siswa tidak akan mendekati atau mencoba benda terlarang itu.

\section{Modus Layanan Bimbingan Konseling Islam Sebagai Upaya Pencegahan Bahaya Narkoba di MAN 3 Medan}

Pelaksanaan pelayanan bimbingan dan konseling islam di MAN 3 Medan sama halnya seperti di MAN 2 Medan, dimana Guru BK berasal dari alumni bimbingan dan konseling dan ada yang merupakan guru fisika yang diperbantukan menjadi Guru BK. Pada dasarnya kegiatan bimbingan dan konseling berjalan dengan baik, hal ini ditandai dengan guru BK membuat program pelayanan setiap tahunnya serta program tersebut di evaluasi oleh pengawas BK.

Dalam program yang dirancang Guru BK, hanya beberapa saja layanan yang mendominasi, serta tidak lupa memasukkan materi tentang pencegahan narkoba dan bahaya narkoba. Selain itu, guru BK tidak hanya memberikan layanan kepada siswa saja. Dalam setahun guru BK memprogramkan untuk memberikan layanan kepada orangtua terkait dengan pegawasan dan kewaspadaan dini kepada peserta didik agar tidak terjerumus memakai narkoba. ide tersebut didasari krena saat ini MAN 3 Medan punya program Siswa Man 3 Medan Anti Narkoba (SISMANTAP). Program ini tidak hanya untuk siswa saja, tetapi tetap merangkul orangtua sebagai pihak pengawas juga. Respon peserta didik terhadap program ini yaitu peserta didik antusias mejadi duta MAN 3 Medan anti narkoba. dan ikut mensosialisasikan bahaya narkoba melalui media sosial yang dimiliki oleh siswa.

Berkaitan dengan sarana prasarana, Ruang BK di MAN 3 Medan Memiliki ukuran luas 4 × 5 meter. Letak sekolah ini 
di pedesaan jadi jauh dari kebisingan lalu lintas. Di sekitar lingkungan sekolah adalah perumahan penduduk setempat sekolah namun ada juga yang jauh rumahnya dari sekolah. sekolah ini tergolong memiliki lingkungan yang kondusif, baik di dalam mapun luar lungkungan sekolah. kemudian letak ruang BK jauh dari kantor TU dan ruang guru namun dekat dengan Mushollah dan kelas-kelas. Berkaitan dengan keterangan yang diberikan oleh Koordinator BK, maka peneliti melakukan penelitian langsung berkaitan dengan sarana dan prasana Bimbingan dan Konseling di MAN 3 Medan. Kesimpulan peneliti, sarana dan prasarana bimbingan dan konseling masih belum representative dan belum mengikuti anjuran sesuai Permendikbud No. 111 Tahun 2014.

Modus Layanan Bimbingan Konseling Islam Sebagai Upaya Pencegahan Bahaya Narkoba di MAPN 4 Medan

Pelaksanaan kegiatan layanan bimbingan dan konseling di MAPN 4 Medan berlangsung seperti pelayanan konseling pada umumnya disekolah. Berdasarkan hasil wawancara dengan Koordinator Guru BK Ibu Jusnida, S.Pd yang menuturkan bahwa saat ini pelayanan MAPN 4 Medan belum terlalu berjalan baik, hal ini dikarenakan masih minimnya SDM Guru BK di MAPN 4 Medan. MAPN 4 Medan sekarang hanya memiliki 2 Guru BK, 1 orang alumni BK, 1 orang lagi diperbantukan sebagai Guru BK. Maka dari itu, untuk memberikan pelayanan yang prima, hendaknya perlu penambahan personel Guru BK yang murni berlatarbelakang bimbingan dan konseling atau bimbingan dan konseling islam.

Berkaitan dengan program layanan, Koordinator Guru BK mengatakan bahwa program layanan sudah disusun hanya berdasarkan need asesmen observasi yang dilakukan oleh Guru BK, hal ini terjadi karena keterbatasan Instrumen seperti AUM UMUM, AUM PTSDL, dan Instrumen non tes lainnya. Seharusnya sebelum penyusunan program, harus melakukan studi kebutuhan (need assesmen) agar program yang disusun lebih tepat sasaran dan tepat tujuan. Kemudian, program yang disusun saat ini sering dievaluasi oleh pengawas BK sehingga pemutakhiran program sering dilakukan setiap beberapa tahun sekali. Program yang disusun notabenenya belum semua terlaksana, kembali lagi ini persoalan keterbatasan waktu, sarana, dan prasarana pelayanan konseling itu sendiri.

Pemilihan materi program layanan biasanya dilakukan hanya melihat isu-isu terkini yang sedang hangat untuk dibahas dengan siswa. Contohnya tentang bullying, narkoba, pergaulan remaja, dan lain-lain. Berkaitan dengan narkoba, pelayanan BK memang sering memuat materi ini, hal ini dikarenakan narkoba sampai saat ini masih musuh semua orang. Sehingga, perlula kiranya kami terus gencar mengkampanyekan anti narkoba walaupun hanya melalui materi dalam layanan BK. Disamping itu juga, layanan BK yang diberikan kepada siswa, harusnya dikaitkan dengan nilai-nilai islami, karena MAPN 4 Medan adalah sekolah yang berlandaskan nilai-nilai islam dan seratus persen siswa MAPN 4 Medan beragama Islam. Maka, Guru BK pun wajib memberikan materi yang dikaitkan dengan nilai-nilai keislaman.

Selanjutnya, jika dibandingkan dengan hasil pengamatan yang peneliti lakukan di MAPN 4 Medan, berkaitan dengan sarana dan prasarana, maka dapat disimpulkan bahwa pada dasarnya belum efektif 
pelayanan konseling di sekolah ini, karena Ruang BK belum memenuhi standar dan kaidah yang telah ditetapkan oleh organisasi profesi yang tertuang dalam Permendikbud No. 111 Tahun 2014. Layanan konseling yang dapat diamatipun hanya beberapa saja yang terlaksana, seperti layanan informasi klasikal, layanan informasi individual, layanan konseling perorangan, dan kegiatan pendukung kunjungan rumah. Selebihnya belum terlaksana dikarenakan keterbatasan waktu dan keterbatasan peralatan yang mendukung pelayanan.

\section{Efektivitas Modus Layanan Bimbingan Konseling Islam Sebagai Upaya Pencegahan Bahaya Narkoba}

Pada dasarnya, untuk melihat efektivitas pelayanan bimbingan dan konseling islam maka perlu melakukan peninjauan terhadap fungsi layanan itu sendiri, diantaranya: 1) Fungsi pemahaman, yaitu fungsi membantu peserta memahami diri dan lingkungan; 2) Fungsi Pencegahan, yaitu fungsi untuk membantu peserta didik mampu mencegah atau menghindari diri dari berbagai permasalahan yang dapat menghambat perkembangan dirinya; 3) Fungsi Pengentasan, yaitu fungsi untuk membantu peserta didik mengatasi masalah yang didalamnya; 4) Fungsi Pemeliharaan dan Pengembangan, yaitu fungsi untuk membantu peserta didik memlihara dan menumbuhkembangkan berbagai potensi dan kondisi positif yang dimilikinya; 5) Fungsi Advokasi, yaitu fungsi untuk membantu peserta didik memperoleh pembelaan atas hak dan atau kepentingannya yang kurang mendapat perhatian.

Berdasarkan hasil wawancara dengan Bapak Amir Husin Pangaribuan, M.Pd, Kons. Sebagai Koordinator Guru BK MAN
1 Medan berkatain dengan efektivitas layanan yang diberikan oleh Guru BK. Layanan BK di MAN 1 Medan di dilakukan oleh Guru BK sesuai dengan SOP yang berlaku dan perangkat layanan lengkap, seperti Rencana Pelaksanaan Layanan (RPL, dahulu disebut Satlan), Program pelayanan bimbingan dan konseling (Tahunan, semesteran, bulanan, mingguan, harian), dan Laporan akhir tahun sebagai pelaporan kepada kepala sekolah terkait dengan kegiatan layanan bimbingan dan konseling dalam setiap tahunnya.

Terdapat perbedaan antara MAN 1 Medan dengan MAN 2 Model Medan terkait masalah bidang pengembangan, dimana MAN 2 Model Medan menambahkan satu bidang pengembangan lagi, yakni bidang pengembangan agama. Ketika peneliti melakukan wawancara kepada Ibu Zuraidah Damanik, S. Psi, di peroleh informasi bahwa 5 bidang yang menjadi dasar dalam perencanaan program BK, dan hal yang mungkin membedakan dari bidang yang ada di MAN 2 Model Medan adalah dengan di sekolah umum lainnya adalah bidang agama. Di madrasah ini bidang agama yang menjadi prioritas utama. Bidang agama tersebut meliputi akidah, ibadah, akhlak, muamalah.

Berdasarkan hasil wawancara yang dikemukakan di atas, maka pada dasarnya program bidang pengembangan yang ada di MAN 2 Model Medan tidak berbeda jauh dengan MAN 1 Medan, hanya saja, MAN 2 Model Medan menambahkan bidang pengembangan BK yakni bidang agama. MAN 2 Model Medan mengelaborasikan bidang pengembangan dari pendapat yang dikemukakan oleh Yahya Jaya yang menyatakan ada 4 jenis bidang Bimbingan Konseling Islami sesuai dengan pembagian aspek agama Islam itu 
sendiri, yaitu: akidah, ibadah, akhlak, dan muamalah.

Selanjutnya, Peneliti melakukan wawancara dengan Guru BK di MAN 3 Medan, yaitu dengan ibu Neneng Chairunnisa, S.Pd yang memberikan informasi bahwa siswa MAN 3 Medan menikmati sekali pelayanan BK yang dilakukan oleh Guru BK. Dalam pelaksanaannya BK tidak menjadi polisi sekolah, tetapi menjadi mitra dan teman bagi siswa, sehingga siswa tidak merasa takut untuk bertemu dan konseling dengan Guru BK.

Selain itu, berkaitan dengan efektivitas modus pelayanan BK di MAN 3 Medan, Wawancara dilakukan dengan Guru BK yaitu dengan Bapak Agus Salim, S.Pd yang memberikan informasi bahwa pelayanan yang dilakukan di MAN 3 Medan termasuk efektiv. Hal ini dilikat dari siswa yang tidak merasa takut untuk bertemu dengan Guru BK, siswa mendengarkan arahan-arahan yang diberikan, dan tidak adanya kasus siswa berkaitan dengan penyalahgunaan narkoba. Program yang disusun pun mengikuti kebutuhan siswa. Sehingga siswa menikmati pelayanan BK yang diberikan oleh Guru BK.

Wawancara juga dilakukan dengan Guru BK MAN 3 Medan yang bukan berlatarbelakang Sarjana Bimbingan dan Konseling yaitu Ibu Jaurah Cut Ali, S.Pd., M.Si.. Informasi yang didapat yaitu berkaitan dengan Guru BK pada dasarnya tidak semua berlatarbelakang bimbingan dan konseling. Tetapi tetap harus mempelajari tentang BK agar pelayanan yang diberikan sama seperti Guru yang berlatar belakang Sarjana BK. Maka dari itu berbagai seminar, lokakarya, workshop berkaitan dengan bimbingan dan konseling terus diikuti agar semakin professional dibidang bimbingan dan konseling.
Madrasah Aliyah Persiapan 4 Medan dalam melaksanakan pelayanan BK masih mengalami kendala yang berarti. Diantaranya, masih tidak diberikan jam klasikal dikelas setiap minggunya dan kurangnya jumlah Guru BK yang tidak sesuai dengan rasio siswa yang seharusnya 1 Guru BK mengasuh 150 siswa. Selain itu, program yang disusun masih belum mengakomodasi seluruh layanan yang ada dalam pola 17 plus. Layanan yang dominan dilakukan diantaranya layanan orientasi, layanan informasi, dan layanan konseling individual. Dikarenakan tidak adanya jam khusus guru BK masuk ke kelas, maka Guru BK memaksimalkan fungsi kerjasama antar guru untuk membimbing siswanya. Begitu juga dalam pelayanan BK, guru sering meminta arahan kepada guru BK terkait penanganan permasalahan siswa. Jika menilai efektivitas, maka belum lah seefektiv sekolah-sekolah yang Guru BK nya sudah sesuai dengan rasio. Tetapi berkaitan dengan penyalahgunaan narkoba, siswa MAN 4 Medan dapat dipastikan belum ada yang berkasus tentang narkoba.

Jika melihat keseluruhan pola pelayanan Bimbingan dan Konseling Islam yang dilakukan di MAN 1 Medan, MAN 2 Medan, MAN 3 Medan, dan MAPN 4 Medan, maka dapat ditarik kesimpulan bahwa pelayanan bimbingan dan konseling islam dilaksanakan dan dirasakan manfaatnya oleh siswa, serta efektif mencegah bahaya narkoba yang ditandai dengan tidak adanya kasus narkoba disetiap sekolah.

\section{PEMBAHASAN}

Jika ditinjau dari konsep bimbingan dan konseling maupun bimbingan dan konseling islam, keseluruhan sekolah telah melaksanakan pola pelayanan yang telah 
dikonsep oleh Prayitno yaitu pola 17 plus yang mengembangkan konsep bidang pelayanan, yaitu: a) Bidang pengembangan pribadi, b) Bidang pengembangan social, c) Bidang pengembangan kegiatan belajar , d) Bidang pengembangan karir, e) Bidang pengembangan kehidupan berkarya, f) Bidang pengembangan kehidupan keberagamaan. Namun dalam BK Pola 17 plus,tidak ada kewajiban tentang proiritas dari implementasi bidang-bidang tersebut.

Selain itu, dalam pelayanan bimbingan dan konseling islam terdapat bidang pengembangan yang cukup berbeda dengan BK Pola 17 Plus. Adapun bidang dalam pelayanan bimbingan dan konseling islam yaitu:

1. Bimbingan Akidah Bimbingan akidah adalah bidang pelayanan yang membantu konseling dalam mengenal, memahami, menghayati, mengamalkan, dan mengembangkan akidah keimanannya, sehingga menjadi pribadi yang beriman dan bertakwa kepada Allah SWT, mantap (istiqamah), dan mandiri (al-kaiyis), sehat dan bahagia, baik lahiriah maupun batiniah, berdasarkan rukun Islam yang enam. Pribadi muwahid adalah tujuan tertingginya.

2. Bimbingan Ibadah Bimbingan ibadah adalah bidang layanan yang membantu konseli dalam mengembangkan hubungan dan pengabdiannya kepada Allah melalui amal ibadah agar menjadi pribadi yang taat dalam mengerjakan perintah-perintah-Nya dan taat dalam menjauhi laranganlarangan-Nya. Pembentukan manusia abid (ahli ibadah) adalah tujuan tertinggi dari pelayanan bimbingan ibadah.
3. Bimbingan Akhlak Bimbingan akhlak adalah bidang pelayanan yang membantu konseli dalam mengembangkan sikap dan perilaku yang baik, sehingga memiliki akhlak mahmuda dan jauh dari akhlak mazmumah. Tujuan yang hendak dicapai oleh bidang bimbingan ini pribadi mulia. Khuluq azhim atau makarim al akhlaq dalam bahasa alQur'an dan hadits.

Bimbingan Muamalah Bimbingan muamalah adalah bidang pelayanan yang membantu konseli dalam membina dan mengembangkan hubungan yang selaras, serasi dan seimbang dengan sesama manusia dan makhluk, sehingga memiliki keharmonisan dalam kehidupan beragama (Jaya, 2000).

\section{SIMPULAN}

Berdasarkan hasil temuan penelitian yang telah dipaparkan, maka dapat ditarik kesimpulan bahwa:

1. Modus pelayanan bimbingan konseling islam di MAN Se-Kota Medan yaitu ada beberapa sekolah yang melaksanakan modus layanan pada kategori sangat baik dan ada beberapa sekolah yang melaksanakan modus layanan pada kategori baik. Hal ini terlihat dari indikatornya yaitu pelaksanaan jenis layanan, kegiatan pendukung, dan penyusunan program yang mengarah pada upaya pencegahan bahaya narkoba.

2. Efektifitas modus layanan bimbingan konseling islam sebagai upaya pencegahan bahaya narkoba di MAN Se-Kota Medan yaitu ada beberapa sekolah pada kategori sangat efektif dan ada beberapa sekolah pada kategori efektif. Hal ini terlihat dari 
indikatornya yaitu layanan yang berjalan sesuai dengan program yang telah disusun, terdapat materi tentang pencegahan bahaya narkoba dalam program yang disusun, tidak adanya kasus narkoba di sekolah, ada SDM yang mencukupi rasio atau tidak.

\section{DAFTAR PUSTAKA}

Aminah \& Nur, A. (2017). BNN Sebut Ada 350 Ribu Pengguna Narkoba di Sumut.
Jaya, Y. (2000). Bimbingan konseling Agama Islam. Padang: Angkasa Raya.

Natawidjaja, R. (1987). PendekatanPendekatan dalam Penyuluhan Kelompok. Jakarta: Depdikbud Dirjen Dikdasmen.

Sumut, P. (2017). BNN: Masyarakat Sumut Berisiko Tinggi Pengguna Narkoba. 